\title{
Small microplastics on beaches of Fernando de Noronha Island, Tropical Atlantic Ocean
}

\author{
Raqueline Cristina Pereira Monteiro ${ }^{1,2 *}\left(\mathbb{0}\right.$, Juliana Assunção Ivar do Sul ${ }^{3,4} \oplus$, Monica Ferreira Costa $^{3}$ \\ ${ }^{1}$ Núcleo de Ecologia Aquática e Pesca da Amazônia - Universidade Federal do Pará - Cidade Universitária Prof. José da Silveira Netto - \\ Avenida Perimetral 2651 - Guamá, Belém- PA - CEP 66075-110 - Brazil \\ ${ }^{2}$ Laboratório de Oceanografia Física Estuarina e Costeira (LOFEC) - Universidade Federal de Pernambuco - Av. Arquitetura, s/n - \\ Cidade Universitária - Recife - PE - CEP: 50740-550 - Brazil \\ ${ }^{3}$ Laboratório de Ecologia e Gerenciamento de Ecossistemas Costeiros e Estuarinos (LEGECE) - Universidade Federal de \\ Pernambuco - Av. Arquitetura, s/n - Cidade Universitária - Recife - PE - CEP: 50740-550 - Brazil \\ ${ }^{4}$ Leibniz Institute for Baltic Sea Research - IOW - Seestraße 15, 18119 Rostock, Germany \\ *Corresponding author: raqmonteiro.oc@gmail.com
}

\section{Abstract}

Oceanic islands are important areas of environmental, social, economic, and scientific interest. Therefore, it is essential to identify pollutants in these environments, including large ( $1 \mathrm{~mm}$ to $\leq 5 \mathrm{~mm}$ ) and small microplastics (SMP) $(1 \mu \mathrm{m}$ to $\leq 1 \mathrm{~mm})$. Here, SMP were identified and characterized in the windward (WW) and leeward (LW) beaches of Fernando de Noronha Island. Samples were collected from $900 \mathrm{~cm}^{2}$ quadrants on the strandline of 15 sandy beaches and were sieved through stainless steel sieves with $1 \mathrm{~mm}$ mesh. The SMP were characterized according to their shape, colour, and size. Synthetic fibres and fragments were identified, and synthetic fibres were predominant. Statistical differences were not found between the WW and LW beaches (160.0 \pm 137.5 particles $\mathrm{m}^{-2}$ and $128.0 \pm 84.3$ particles $\mathrm{m}^{-2}$, respectively; Mann-Whitney $U$ test: $U=198.5 ; p=0.81)$ in relation to the total amount of SMP deposited on the beaches. Also, both types/ shapes were present in the two groups of beaches (Friedman's test, $X^{2} r=6.09 ; p=0.91$ ). The environmental forcings controlling the transport and potential deposition of synthetic fibres may have been different from those acting on fragments that more resembled the grains of sand in the beaches. Although it is difficult to prevent allochthonous sources of SMP at the small scale, management actions on the island are mandatory to prevent autochthonous sources.

Descriptors: Plastic pollution, Oceanic islands, Marine conservation, Atlantic Ocean, Brazil.

\section{INTRODUCTION}

Scientists, civil society, and governments have recently $(<10 \mathrm{y})$ increasing concerns about the impacts of microplastic pollution on marine ecosystems ( $\mathrm{Hu}$ et al., 2019; Van Wijnen et al., 2019). Microplastics are plastic particles with a size of $1 \mu \mathrm{m}$ to $5 \mathrm{~mm}$; because they have diverse behaviours within marine habitats (i.e. transport mechanisms and potential impacts), they can be classified as large $(1 \mathrm{~mm}$ to $\leq 5 \mathrm{~mm})$ or small $(1 \mu \mathrm{m}$ to $\leq 1 \mathrm{~mm}$ ) microplastics (SMP) (Van Cauwenberghe et

Submitted on: 3/December/2018

Approved on: 11/November/2019

Associate Editor: Alexander Turra

Editor: Rubens M. Lopes

() 2019 The authors. This is an open access article distributed under the terms of the Creative Commons license. al., 2015; Gigault et al., 2018). However, SMP and large microplastics have the same sources (Boucher and Friot, 2017). Primary SMP are already at the microscopic scale when they reach the sea, such as microbeads used in cosmetics; they can enter marine environments from sewage discharge on land (Browne et al., 2011; Boucher and Friot, 2017). On the other hand, secondary SMP originate from the degradation and fragmentation of relatively larger plastics in the environment (Frias and Nash, 2019).

Generally, the smaller the size of the microplastics, the greater the number of marine animals susceptible to interaction (e.g. ingestion) with these particles; they then have the potential to be introduced into marine trophic webs (Gusmão et al., 2016; Wang et al., 2019). Also, the harmful effects of SMP are potentially worse when organic or inorganic pollutants are adsorbed onto 
SMP, as they can be released into the digestive tract of organisms, thereby even compromising human food security (Barboza et al., 2018).

Within the range of marine habitats that are already shown to be contaminated by microplastics are remote oceanic islands, where allochthonous sources (e.g. marine currents and ships) can be significant sources of plastics with a relatively larger size range (Edo et al., 2019; Lavers et al., 2019; Ryan et al., 2019). Plastic particles are commonly found in higher amounts on windward (WW) beaches of these islands owing to the direct action of physical forcing (e.g. Ivar do Sul et al., 2009; Monteiro et al., 2018). On the other hand, autochthonous sources are significant on touristic islands where there is permanent human occupation (Debrot et al., 2013; Schmuck et al., 2017). Independent of the predominant source of plastic, oceanic islands can be sources but also temporary reservoirs or final sinks of plastics in the oceans.

In the Atlantic Ocean, the UNESCO Natural Heritage of Humanity island of Fernando de Noronha covers approximately $20 \mathrm{~km}^{2}$; approximately 3,000 inhabitants live on the island (IBGE, 2010), but the number of tourists reaches $>50,000$ in the high season (austral summer season). The island is part of the Environmental Protection Area of Fernando de Noronha - Rocas - Saint Pedro and Saint Peter Archipelago and the National Marine Park of Fernando de Noronha (PARNAMAR). It has a crucial role in the preservation of threatened species such as marine turtles (Caretta caretta, Chelonia mydas, and Eretmochelys imbricata), fish (Lemon Shark - Negaprion brevirostris), seabirds (Shearwater - Puffinus Iherminieri), and echinoderms (Starfish - Echinaster (Othilia) guyanensis). In addition, the Golfinhos Bay hosts a permanent population of rotator dolphins (Stenella longirostris) (Bellini and Sanches, 1996; Serafini et al., 2010). All endemic and migratory species are at imminent risk of plastic pollution on the island.

This study is part of a broader project on microplastic pollution in Brazilian oceanic islands. Sediment samples were fractionated with a $1 \mathrm{~mm}$ sieve, and large microplastics and SMP were preferentially retained in two different fractions. Large microplastic data were previously published (Ivar do Sul et al.,

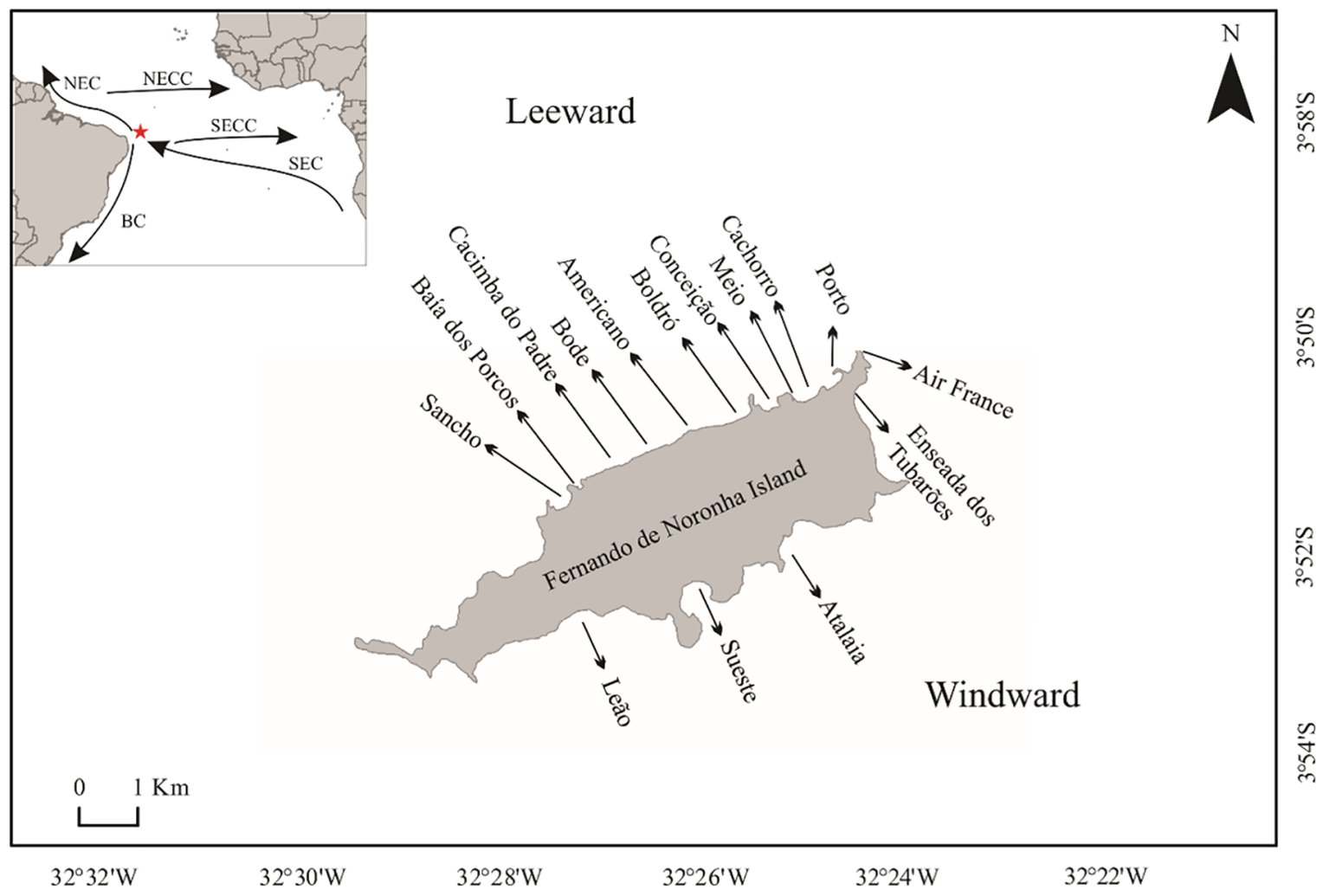

Figure 1. (A) Location of the Fernando de Noronha Island in the west of the Equatorial Atlantic Ocean and the main surface currents (SEC = Equatorial South Current; NBC = Northern Brazil Current; BC = Brazilian Current, SECC = South Equatorial Counter Current; NECC = North Equatorial Counter Current). (B) Location of beaches analyzed on the main island of Fernando de Noronha, divided into leeward and windward. 
2017). Thus, the present study aimed to identify and characterize SMP in sandy beaches of Fernando de Noronha Island. Here we focused on SMP with a small spatial distribution and tested two hypotheses, as follows: (1) WW beaches are more contaminated by SMP than LW beaches and (2) are recurrent among the WW and LW beaches on the island.

\section{MATERIAL AND METHODS}

\section{STUDY AREA}

Fernando de Noronha is a volcanic archipelago located in the Tropical Atlantic Ocean (Figure 1). Its geological nature is formed by submarine volcanic mountains emerging from the fracture zone of Fernando de Noronha (Calliari et al., 2016), and it forms 21 small islands and cliffs. The weather is tropical with an average annual air temperature of $28 \pm 4^{\circ} \mathrm{C}$ (Mohr et al., 2009). It has two defined seasons, namely the rainy season from February to July and the dry season from August to January (Mohr et al., 2009). The island is influenced by the southeast trade winds, which are more intense in June-August and create higher swells on the WW side of the archipelago (Calliari et al., 2016). The samples used in this study were collected in the austral summer season (March) before the higher swells reached the island. The islands are also under the influence of the South Equatorial Current (SEC) (Cirano et al., 2006), which flows from east to west and has a low concentration of suspended matter (Eston et al., 1986; Stramma and England, 1999). The local hydrodynamics and island topography generate vertical turbulence that allows the rise of deeper waters rich in nutrients (upwelling), thereby increasing the plankton biomass, which is a phenomenon called the island mass effect (Lira et al., 2014; Tchamabi et al., 2017).

The main island of the Fernando de Noronha Archipelago, which is also called Fernando de Noronha, has $37 \mathrm{~km}$ of coastline, of which $28.5 \mathrm{~km}$ (77\%) are rocky shores and $8.4 \mathrm{~km}$ (23\%) forms 32 beaches with 15 sandy beaches (Calliari et al., 2016). These sandy beaches are composed of carbonate sand, which is derived from coral reefs and volcanic rocks, with grain sizes varying from $0.1 \mathrm{~mm}$ to $0.5 \mathrm{~mm}$ (Barcellos et al., 2011; Manso et al., 2011). For this study, beaches were grouped by WW beaches, which are directly influenced by wind, marine currents, and waves; and LW beaches, which are relatively protected from the action of wind and currents.

\section{SAMPLING AND SAMPLE TREATMENT}

Sediment samples were collected on the strandline of five WW and ten LW beaches by scraping the sand from $30 \times 30 \mathrm{~cm}\left(900 \mathrm{~cm}^{2}\right)$ quadrants (Ivar do Sul et al., 2009). Three quadrants were sampled on each beach with one at the centre and two at each end of the beach arc. However, only one quadrant (in the centre) was sampled on Porcos and Cachorro beaches and two quadrants (at the ends of the beach arc) were sampled on Porto beach owing to the beach lengths (total of 40 samples). All samples were kept in sealed plastic bags until analysis. Particles resembling these bags were not identified in the samples; thus, they were not considered a potential contamination source of microplastics here.

In the laboratory, sediment samples were ovendried and sieved through a stainless steel mesh of $1 \mathrm{~mm}$. The fraction smaller than $1 \mathrm{~mm}$ (SMP + sediment) was then submitted to density separation following wellestablished methods (e.g. Martins and Sobral, 2011) previously detailed by Pinheiro et al. (2019). Negative blanks were performed to control possible contamination from the commercial table salt and distilled water used for density separation. Particles (including fibres) resembling those presented in this study were not identified in the blank samples and were not considered potential sources of SMP here. Filters were oven-dried in Petri dishes at $40^{\circ} \mathrm{C}$ and analysed under Carl Zeiss Stemi 2000-C stereomicroscope (1x). During the laboratory procedures, samples were kept closed with a glass lid or Al foil to avoid external contamination (i.e. airborne fibres). SMP particles were identified according to their type/shape (e.g. fragments or synthetic fibres), colour, and size (length and total area). Fibres were recognized using visual criteria available in the literature, including the uniform diameter of fibres or the presence of bends, or by their brightness and diverse colours (i.e. blue and red), which did not resemble marine animal or plant tissue (Browne et al., 2011). Images were obtained using AxioVs40 V 4.8.2.0 software from Carl Zeiss Vision.

\section{DATA ANALYSES}

The total density (amounts) of SMP was expressed as the number of particles per square metre. The size of the SMP was expressed in millimetres and the area was 
expressed in square metres. The Gaussian distribution of the data was tested, and the data showed a nonparametric distribution. The nonparametric Mann-Whitney $U$ test ( $a=0.05$ ) was then used to check the significant differences in the amount of SMP between WW and LW beaches (Hypothesis 1). To compare the SMP types within beach groups (WW or LW), a two-way analysis with Friedman's test $(a=0.05)$ was used for multiple comparisons (Hypothesis 2). Data were also compared with those of a previous work (Ivar do Sul et al., 2017) to check the co-occurrence of SMP and relatively larger microplastics in beaches on the island.

\section{RESULTS}

SMP were reported in all sediment samples from Fernando de Noronha Island (Figure 2). A total of 504 SMP particles were identified. Synthetic fibres corresponded to $90 \%$ ( $n=459$ ) (Figure 3) and fragments accounted for approximately $10 \%(n=45)$ of the particles. Synthetic fibres were predominant in all beaches and quadrats, except for one quadrat from Meio Beach (Table 1). Other types of SMP (e.g. microbeads) were not detected at this time.

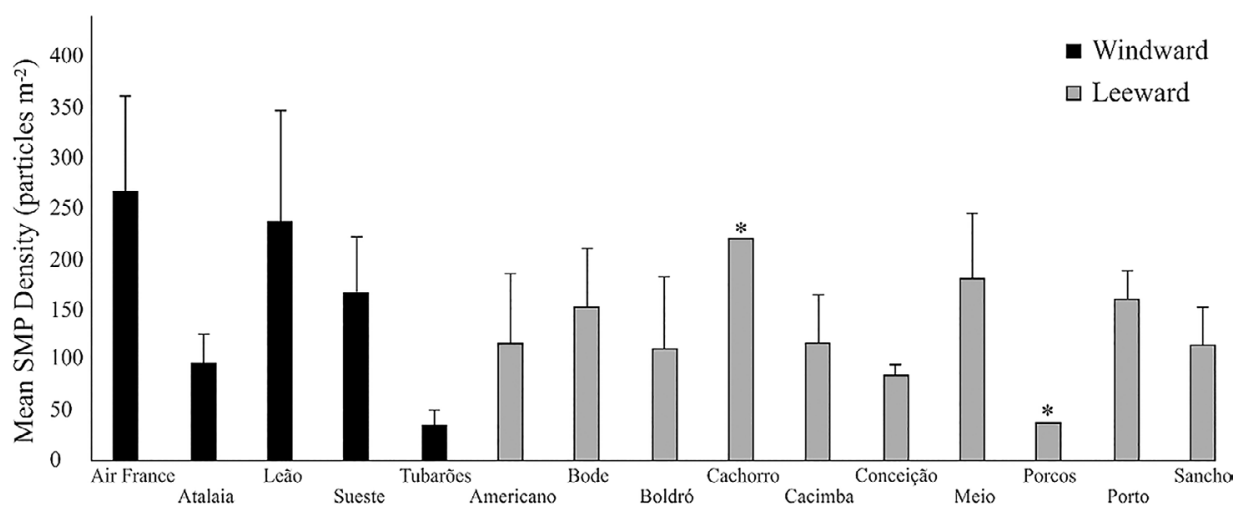

Figure 2. Mean SMP density (particles $\mathrm{m}^{-2}$ ) on the windward and leeward beaches of Fernando de Noronha Island, Tropical Atlantic Ocean. *Total values of Porcos and Cachorro beaches. Error bars represent the standard error.

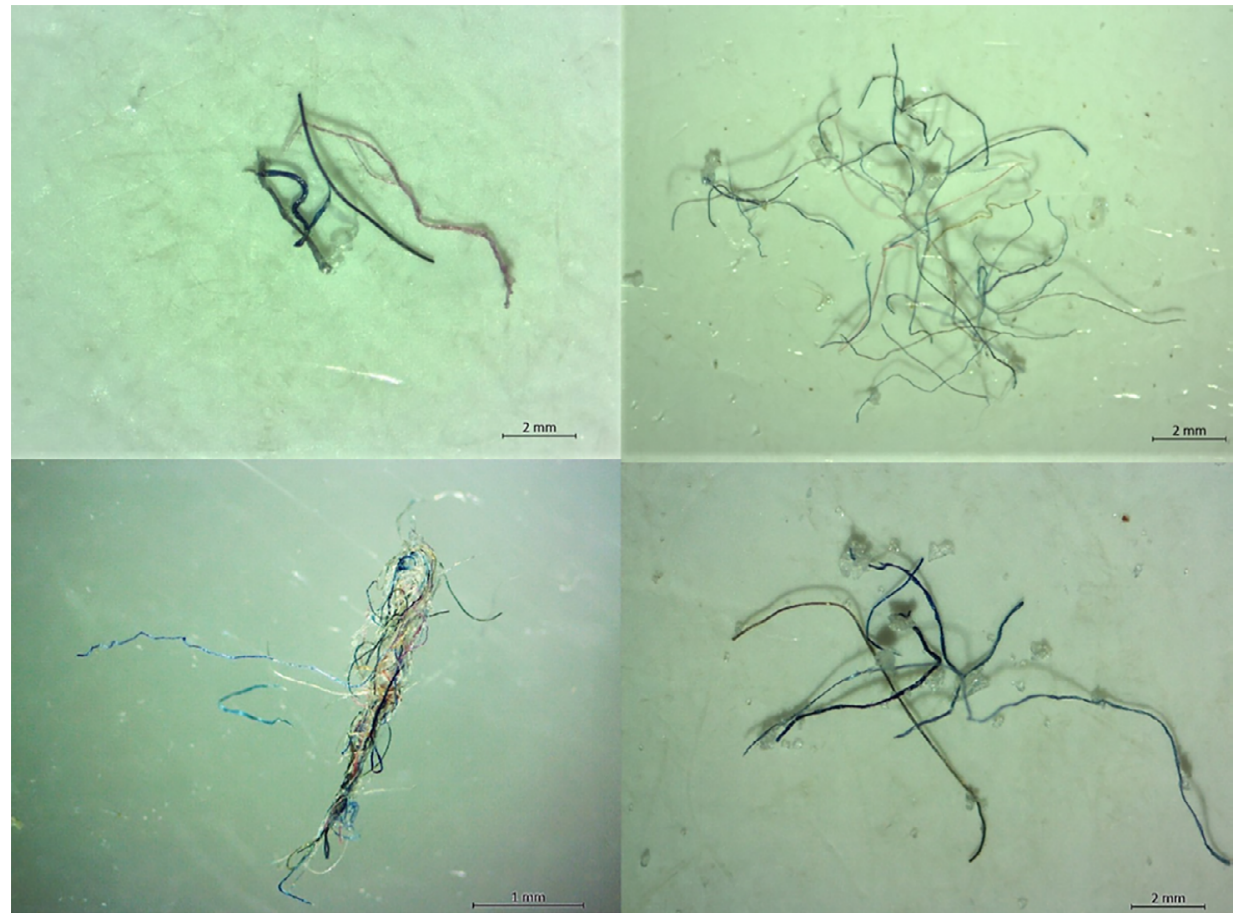

Figure 3. Photographic examples of synthetic fibres found on beaches of Fernando de Noronha Island. 
Table 1. Density, size e area of fragments and synthetic fibres found on windward and leeward beaches of Fernando de Noronha Island, Tropical Atlantic Ocean. E - East; M - Middle; W - West. *Underestimated.

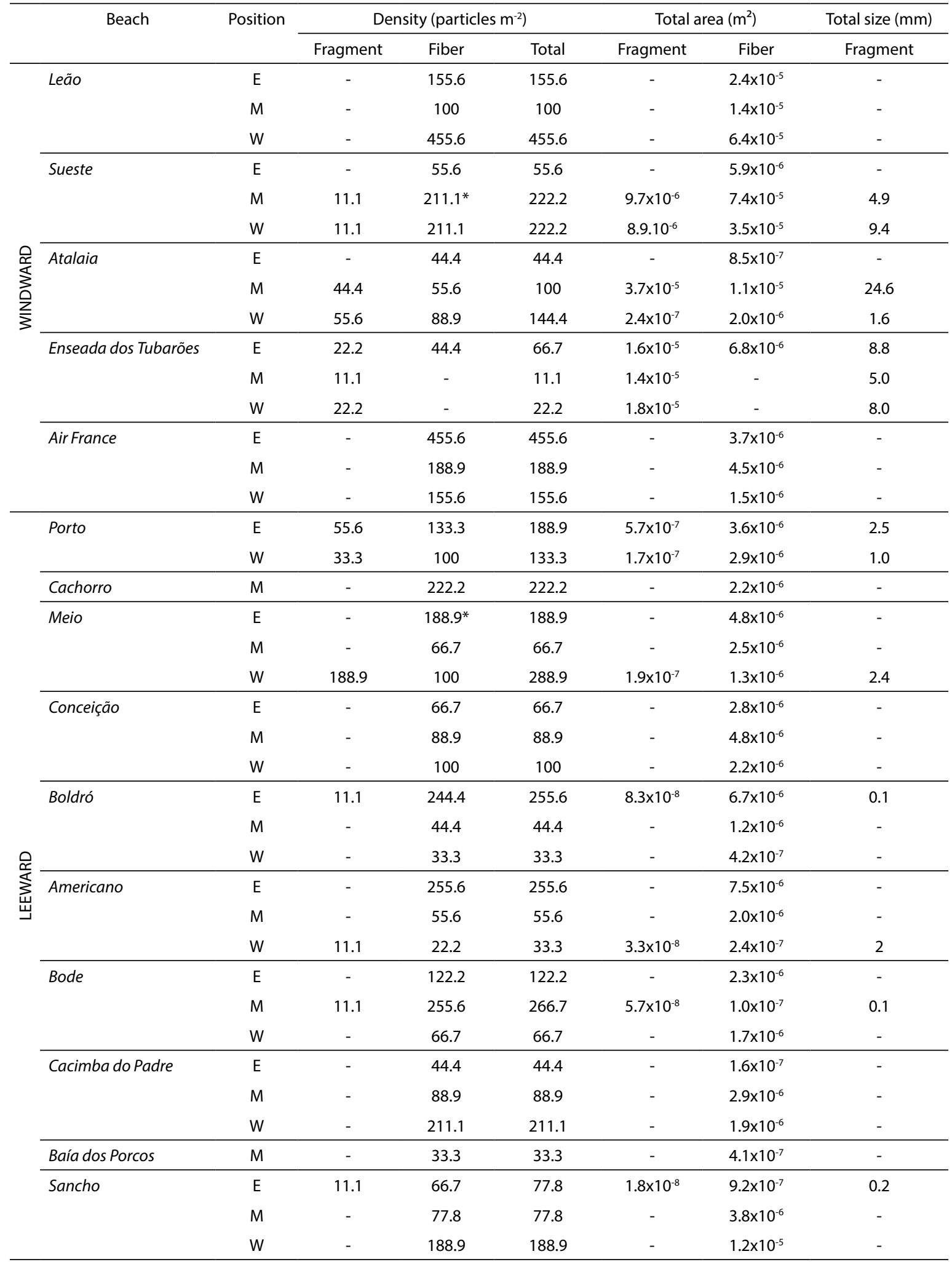


The mean size of the particles (MSP) was $1.8 \pm 4.5 \mathrm{~mm}$ $\left(\mathrm{MSP}_{\mathrm{ww}}=4.2 \pm 6.7 \mathrm{~mm} ; \mathrm{MSP}_{\mathrm{LW}}=0.3 \pm 0.8 \mathrm{~mm}\right.$ ) (Table 1). The mean size was larger than $1 \mathrm{~mm}$ because longer fibres were not consistently retained by the $1 \mathrm{~mm}$ sieve when the sample was sieved. If all the particles were sorted on a Petri dish, then fragments would occupy an area of $1.06 \times 10^{-4} \mathrm{~m}^{2}$ (Total area $_{w w}=1.05 \times 10^{-4} \mathrm{~m}^{2}$; Total Area $_{\mathrm{LW}}=1.10 \times 10^{-6} \mathrm{~m}^{2}$ ) while synthetic fibres would occupy a relatively larger area of $3.20 \times 10^{-4} \mathrm{~m}^{2}$ (Total area $_{w w}=2.50 \times 10^{-4} \mathrm{~m}^{2}$; Total area $\left.\mathrm{Lw}=7.30 \times 10^{-5} \mathrm{~m}^{2}\right)($ Table $1)$.

Regarding colours, blue, black, and colourless synthetic fibres represented nearly $100 \%$ of the plastic particles, except for a few pink/reddish coloured fibres. Among the fragments, blue fragments were predominant among SMP (80.0\%; 36 particles), followed by green fragments (11.1\%; 5 particles). Other colours such as white, yellow, gray, and red each represented 2.2\% (Figure 4).

The amount of SMP in the WW and LW beaches ranged from $33.3 \pm 16.9$ particles $\mathrm{m}^{-2}$ to $266.6 \pm 94.9$ particles $\mathrm{m}^{-2}$ and from $85.1 \pm 9.7$ particles $\mathrm{m}^{-2}$ to $181.4 \pm 64.2$ particles $\mathrm{m}^{-2}$, respectively. There was no statistical difference between these groups of beaches (WW beaches $=160.0 \pm 137.5$ particles $\mathrm{m}^{-2}$; LW beaches $=128.0 \pm 84.3$ particles $\mathrm{m}^{-2}$; MannWhitney $U$ test: $U=198.5$; $p=0.81$ ) when considering the total amount of SMP, so Hypothesis 1 was not corroborated.
However, the amounts of SMP were more variable among WW beaches than among LW beaches (Figure 2). In general, Air France and Leão beaches presented the highest amounts of SMP as they were both located on the WW side of the island. Considering the types of SMP, synthetic fibres and fragments were present in both WW and LW beaches (Friedman's test, $X^{2} r=6.09 ; p=0.913$ ), thereby corroborating Hypothesis 2.

While large microplastics were previously reported on 8 of 13 beaches (Ivar do Sul et al., 2017), SMP were present on 9 of 15 beaches (Figure 5). However, both microplastic size categories co-occurred on five beaches, with three on the WW side of the island (i.e. Enseada dos Tubarões, Atalaia, and Sueste) and two on the leeward side (i.e. Bode and Porto).

\section{DISCUSSION}

Fernando de Noronha was a key island to test the hypotheses presented in this study because it is relatively isolated from the continent and directly influenced by the SEC (Figure 1), but is also inhabited and receives thousands of tourists each year (Cristiano et al., 2020). Thus, plastics were expected to originate from both allochthonous and autochthonous sources, including microplastics (Ivar do Sul et al., 2009). Although the occurrence of microplastics in relatively larger size ranges was already reported in beaches and

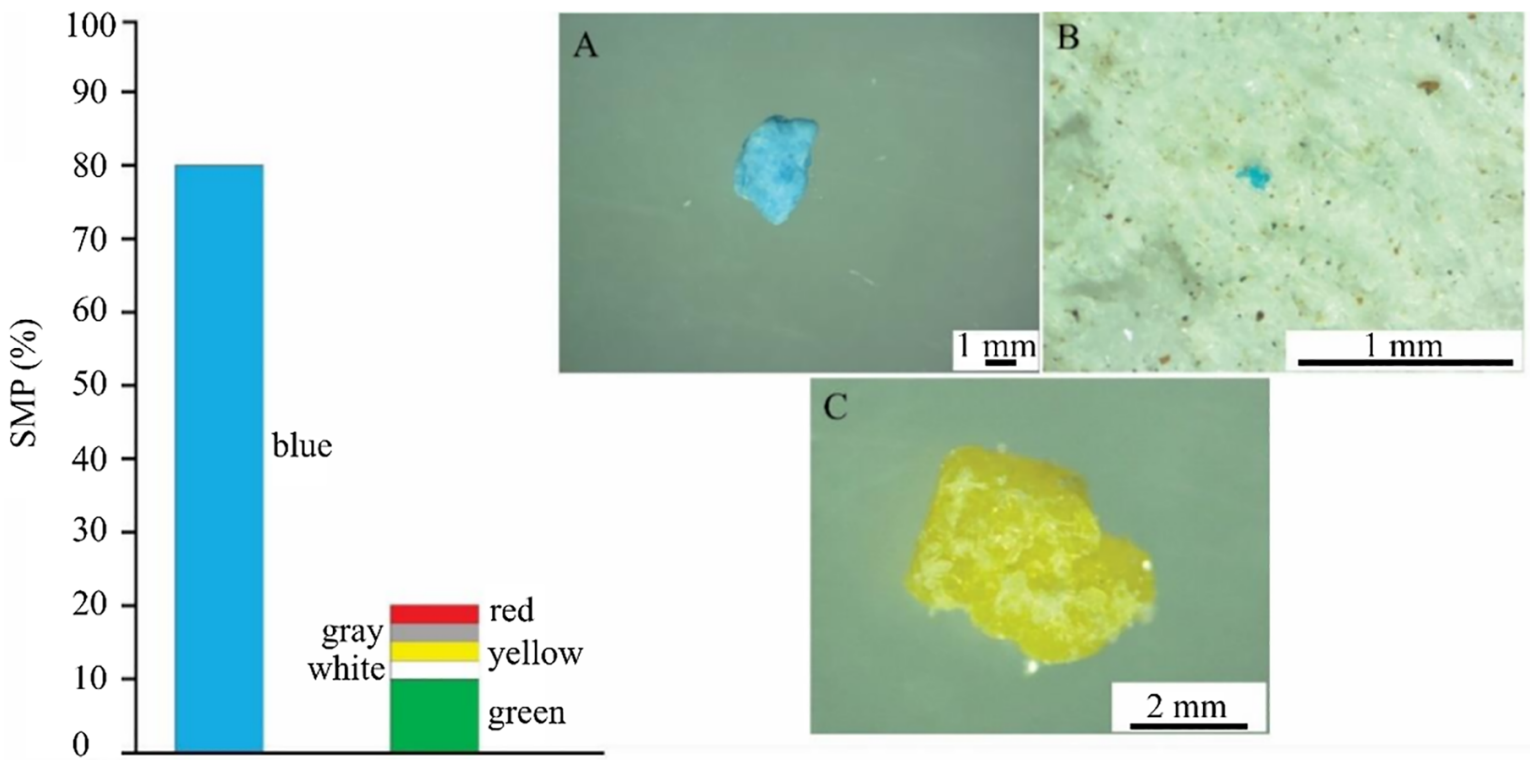

Figure 4. Colours of the plastic fragments identified on the windward and leeward beaches in Fernando de Noronha Island, Tropical Atlantic Ocean, $\mathrm{N}=45$ plastic particles. A) Blue plastic fragment collected at Tubarão beach; B) Plastic fragment collected at Meio beach; C) Fragment plastics collected on the beach. 


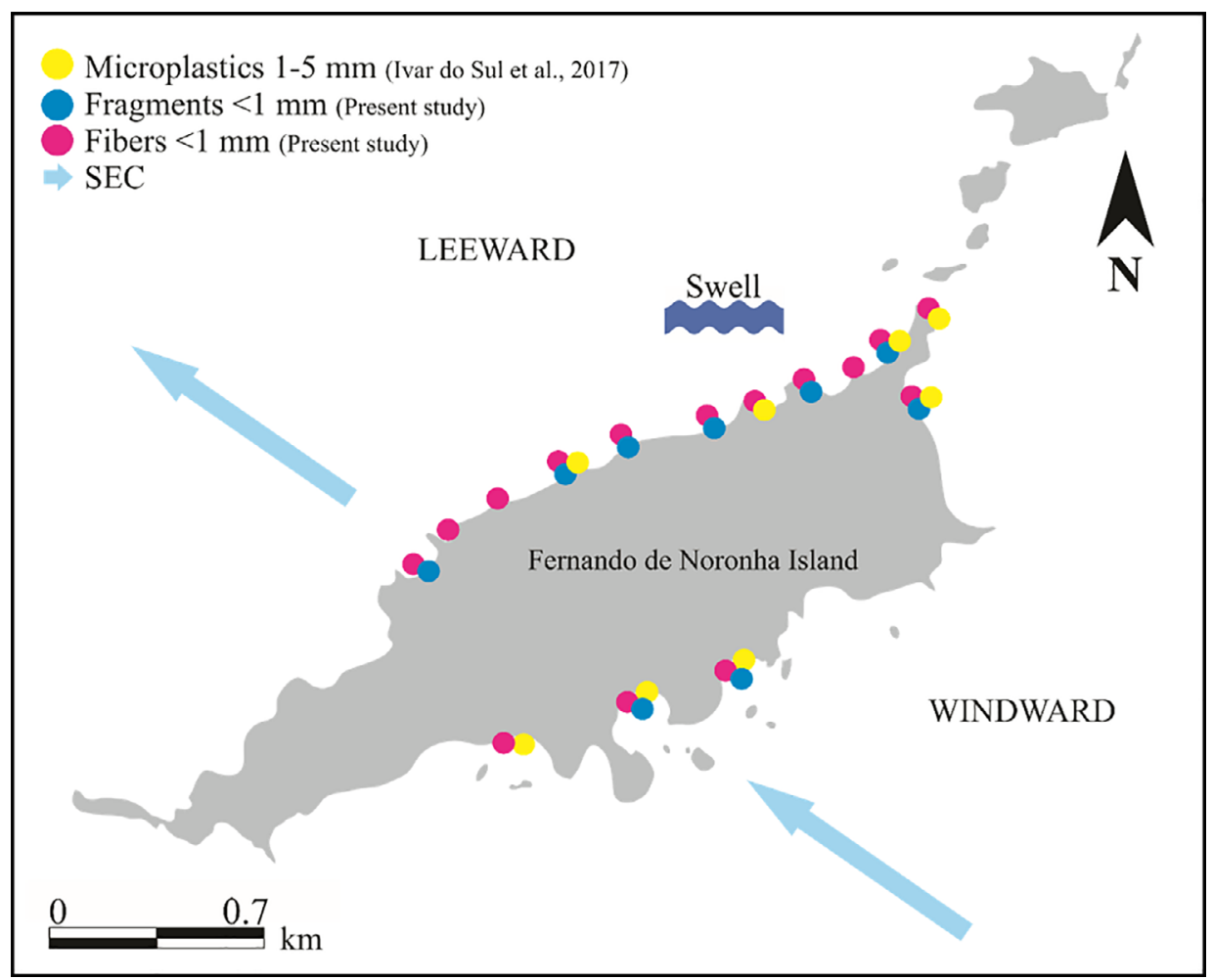

Figure 5. Larger microplastics fraction between 1-5 mm (Ivar do Sul et al., 2017)', a fraction less than $1 \mathrm{~mm}$ (this study) ${ }^{2}$ found on the beaches in the windward and leeward of the Island of Fernando de Noronha, Tropical Atlantic Ocean. SEC: South Equatorial Current; 'Total of 13 beaches sampled, Porcos and Cachorro beaches have not sampled in this work; ${ }^{2}$ Total of 15 beaches sampled, including Porcos and Cachorro beaches.

in the surface waters around the island (Ivar do Sul et al., 2013 ; 2017), this study reported microplastics $<1 \mathrm{~mm}$ for the first time.

Sources of microplastics in the small size range are more difficult to identify compared with those of larger plastics. Based on the sampling strategy used in this study, no statistical difference was reported between the WW and LW beaches in relation to the amount of SMP. This indicated that independent of physical forcing and potential transport of allochthonous plastic particles, microplastics in this size range accumulated in the island beaches. On the other hand, the predominance of relatively larger microplastics (mostly fragments) in the WW beaches (Ivar do Sul et al., 2009; 2017) indicated a clearer influence of surface ocean currents on their transport and deposition on beaches. This was expected because the microplastic fragments were similar in size and shape to the grains on sandy beaches; therefore, their dynamics within the beach environment were expected to resemble sediment movement/deposition. Thus, the results presented here were influenced by the predominance of synthetic fibres (which were absent in the previous study), which had multiple and distinguished sources compared with the fragments. In addition, the deposition/removal of fibres was likely controlled by different environmental forcings; for example, local sources (i.e. wastewater discharge) and winds may have had more influence on their potential accumulation.

The results showed that WW beaches presented higher variability among beaches in relation to the amount of SMP (Figure 2). This may have been due to different small-scale current patterns, the dominant grain size in the beaches, wave action, and/or relative wind exposure. The influence of the island mass effect (Tchamabi et al., 2017) on microplastics distribution must still be investigated. It may have played a special role mainly in the transport of fibres within the insular platform and finally on their deposition on the island beaches.

The predominance of fibres was reported in previous studies, including studies on sea ice in the Arctic Ocean and in the air around an urban city (Dris et al., 2016; Bergmann et al., 2019). In the marine environment, sources are commonly associated with wastewater, but 
it has been shown that fishing equipment and other items can also release fibres into the sea (Mishra et al., 2019). For example, in the Saint Pedro and Saint Paulo Archipelago, which is approximately $500 \mathrm{~km}$ from Fernando de Noronha, industrial fishing is considered a potential source of pelagic synthetic fibres (Ivar do Sul et al., 2013). Therefore, local fishing was a possible a source of fibres in this study. Large fishing equipment (including nets and fishing lines) was previously reported to be submerged in the PARNAMAR area of the island (Link et al., 2019), and some of these items have been recognized as sources of fibres in the sea.

The potential impacts of SMP, including fibres, include their potential ingestion by organisms from the benthos community. For example, small arthropods of the order Collembola (Hexapoda: Entognatha) inhabit interstitial sediments and soils on the island (Lima and Zeppelini, 2015; Palacios-Vargas et al., 2013). They can carry organic and inorganic particles in the same size range as SMP particles within sediment layers, so there is the potential for them to also transport those SMP that would then be available to other organisms in the sediment (Maaß et al., 2017). If ingested, SMP may decrease the feeding and locomotion capacity of organisms through physical or chemical (persistent organic pollutants and heavy metals) effects (Besseling et al., 2013). Also, as organisms in the benthos support organisms in higher trophic levels, the availability of SMP may introduce these particles in the trophic web and have unknown consequences on the insular ecosystem.

Although the ingestion of fibres has been reported for organisms in different levels within marine food webs, there are very few insights related to the preferential colour that is ingested. Fibres samples in this study were mainly blue and/ or black, which fit with most of the fibres that were previously reported to be ingested by polychaetes in the Atlantic and Mediterranean seas and were also in the same size range (i.e. 2-4 mm) (Gusmão et al., 2016). Moreover, blue and black fibres (77\%) were also reported to be prevalent over other microplastic particles ingested by the Atlantic ghost crab (Costa et al., 2019). Based on the results presented here, there is a real potential of ingestion of fibres deposited on sandy beaches. Endemic, resident, and migratory species on the island are at imminent risk of microplastic ingestion.

\section{CONCLUSION}

The presence of SMP pollution on Fernando de Noronha Island, which is a hotspot of marine biodiversity, was confirmed for the first time. Future studies about (micro)plastic pollution should consider meteorological and oceanographic forcing, seasonality, beach morphodynamics, and anthropogenic influences to allow the understanding of the accumulation and removal processes of SMP in the beaches of Fernando de Noronha Island. Finally, island managers should determine ways to prevent and remediate the plastic pollution on the island to ensure a healthy marine ecosystem for future generations, such as the District Decree $\mathrm{N}^{\circ} 002$ approved in December 12th, 2018 that provides for the prohibition of single-use plastics in the island.

\section{ACKNOWLEDGEMENTS}

Raqueline Monteiro thanks the CAPES-Brazilian Education Ministry for the MPhil and PhD scholarships, and INCT Program for the scholarships - MCTI/CNPq/ CAPES/FAPs no 16/2014). Juliana Ivar do Sul thanks the CAPES-Brazilian Education Ministry and Federal University of Rio Grande for the Postdoc scholarship. Monica Costa is a CNPq fellow. We thank CNPq (Project 557184/2009-6) for financial support to the Project and MSc. Marcos Silva for collaboration with the figures presented in this paper. We also thank the editor and referees for their contributions to improve the manuscript.

\section{AUTHOR CONTRIBUTIONS}

R.C.P.M.: Methodology, Validation, Formal analysis, Investigation, Writing - Original Draft, Writing - Review \& Editing, Visualization.

J.A.S.: Conceptualization, Methodology, Validation, Writing - Original Draft, Writing - Review \& Editing, Supervision, Funding acquisition.

M.F.C.: Conceptualization, Methodology, Validation, Resources, Writing - Original Draft, Writing - Review \& Editing, Supervision, Project administration, Funding acquisition.

\section{REFERENCES}

BARBOZA, L. G. A., VETHAAK, A. D., LAVORANTE, B. R., LUNDEBYE, A. K. \& GUILHERMINO, L. 2018. Marine microplastic debris: An emerging issue for food security, food safety and human health. Marine Pollution Bulletin, 133, 336-348.

BARCELLOS, R. L., COELHO-JÚNIOR, C., LINS, S. R. R. M., SILVA, M. S., CAMARGO, P. B. \& TRAVASSOS, P. E. P. F. 2011. Island beaches morphological and sedimentary short term variations - the case of SE Fernando de Noronha Island, South Atlantic, Brazil. Journal of Integrated Coastal Zone Management, 11, 471-478.

BARNES, D. K., GALGANI, F., THOMPSON, R. C. \& BARLAZ, M. 2009. Accumulation and fragmentation of plastic debris in global 
environments. Philosophical Transactions of the Royal Society B, Biological Sciences, 364, 1985-1998.

BELLINI, C. \& SANCHES, T. M. 1996. Reproduction and feeding of marine turtles in the Fernando de Noronha Archipelago, Brazil. Marine Turtle Newsletter, 74, 12-13.

BERGMANN, M., MÜTZEL, S., PRIMPKE, S., TEKMAN, M. B., TRACHSEL, J. \& GERDTS, G. 2019. White and wonderful? Microplastics prevail in snow from the Alps to the Arctic. Science Advances, 5, 1157.

BESSA, F., BARRÍA, P., NETO, J. M., FRIAS, J. P., OTERO, V., SOBRAL, P. \& MARQUES, J. C. 2018. Occurrence of microplastics in commercial fish from a natural estuarine environment. Marine Pollution Bulletin, 128, 575-584.

BESSELING, E., WEGNER, A., FOEKEMA, E. M., VAN DEN HEUVELGREVE, M. J. \& KOELMANS, A. A. 2013. Effects of Microplastic on Fitness and PCB Bioaccumulation by the Lugworm Arenicola marina (L.). Environmental Science \& Technology, 47, 593-600.

BOUCHER, J. \& FRIOT, D. 2017. Primary Microplastics in the Oceans: A Global Evaluation of Sources, Gland, Switzerland: IUCN.

BROWNE, M. A., CRUMP, P., NIVEN, S. J., TEUTEN, E., TONKIN, A., GALLOWAY, T. \& THOMPSON, R. 2011. Accumulation of microplastic on shorelines worldwide: Sources and sinks. Environmental Science and Technology, 45, 9175-9179.

CALLIARI, L. J., PEREIRA, P. S., SHORT, A. D., SOBRAL, F.C., MACHADO, A. A., PINHEIRO, Y. G. \& FITZPATRICK, C. 2016. Sandy Beach of Brazilian Oceanic Islands. Brazilian Beach Systems, 543-571.

CHEN, Q., LI, Y. \& LI, B. 2020. Is color a matter of concern during microplastic exposure to Scenedesmus obliquus and Daphnia magna?. Journal of Hazardous Materials, 383, 121-224.

CIRANO, M., MATA, M. M., CAMPOS, E. J. D. \& DEIRÓ, N. F. R. 2006. A Circulação oceânica de larga-escala na região oeste do Atlântico Sul com base no modelo de circulação global OCCAM. Revista Brasileira de Geofísica, 24, 209-230.

COSTA, L. L., ARUEIRA, V. F., DA COSTA, M. F., DI BENEDITTO, A. P. M. \& ZALMON, I. R. 2019. Can the Atlantic ghost crab be a potential biomonitor of microplastic pollution of sandy beaches sediment? Marine Pollution Bulletin, 145, 5-13.

COSTA, M. F., IVAR DO SUL, J. A., SILVA-CAVALCANTI, J. S., ARAÚJO, M. C. B., SPENGLER, Â. \& TOURINHO, P. S. 2010. On the importance of size of plastic fragments and pellets on the strandline: a snapshot of a Brazilian beach. Environmental Monitoring and Assessment, 168, 299-304.

CRISTIANO, S. C., ROCKETT, G. C., PORTZ, L. C. \& SOUZA FILHO, J. R. 2020. Beach landscape management as a sustainable tourism resource in Fernando de Noronha Island (Brazil). Marine Pollution Bulletin, 150, 110-621.

DEBROT, A. O., VAN RIJN, J., BRON, P. S. \& DE LEÓN, R. 2013. A baseline assessment of beach debris and tar contamination in Bonaire, Southeastern Caribbean. Marine Pollution Bulletin, 71, 325-329.

DOMINGUEZ, P. S., ZEINEDDINE, G. C., ROTUNDO, M. M., BARRELLA, W. \& RAMIRES, M. 2016. A pesca artesanal no Arquipélago de Fernando de Noronha (PE). Boletim do Instituto de Pesca, 42, 241-251.

DRIS, R., GASPERI, J., SAAD, M., MIRANDE, C. \& TASSIN, B. 2016. Synthetic fibers in atmospheric fallout: A source of microplastics in the environment? Marine Pollution Bulletin, 104, 290-293.
EDO, C., TAMAYO-BELDA, M., MARTÍNEZ-CAMPOS, S., MARTÍNBETANCOR, K., GONZÁLEZ-PLEITER, M., PULIDO-REYES, G., GARCÍA-RUIZ, C., ZAPATA, F., LEGANÉS, F., FERNÁNDEZPIÑAS, F. \& ROSAL, R. 2019. Occurrence and identification of microplastics along a beach in the Biosphere Reserve of Lanzarote. Marine Pollution Bulletin, 143, 220-227.

ESTON, V. R., MIGOTTO, A. E., OLIVEIRA FILHO, E. C., RODRIGUES, S. A. \& FREITAS, J.C. 1986. Vertical distribution of benthic marine organisms on rocky coasts of the Fernando de Noronha archipelago (Brazil). Boletim do Instituto Oceanográfico, 34 37-53.

GIGAULT, J., TER HALLE, A., BAUDRIMONT, M., PASCAL, P. Y., GAUFFRE, F., PHI, T. L., EL HADRI, H., GRASSL, B. \& REYNAUD, S. 2018. Current opinion: What is a nanoplastic? Environmental Pollution, 235, 1030-1034.

GUSMÃO, F., DI DOMENICO, M., AMARAL, A. C. Z., MARTÍNEZ, A., GONZALEZ, B. C., WORSAAE, K., IVAR DO SUL, J. A. \& CUNHA LANA, P. 2016. In situ ingestion of micro fibres by meiofauna from sandy beaches. Environmental Pollution, 216, 584-590.

HU, D., SHEN, M., ZHANG, Y., LI, H. \& ZENG, G. 2019. Microplastics and nanoplastics: would they affect global biodiversity change? Environmental Science and Pollution Research, 26, 19997-20002.

IBGE (INSTITUTO BRASILEIRO DE GEOGRAFIA E ESTATÍSTICA). 2010. Censo Demográfico 2010. Rio de Janeiro, IBGE.

IMHOF, H. K., LAFORSCH, C., WIESHEU, A. C., SCHMID, J., ANGER, P. M., NIESSNER, R. \& IVLEVA, N. P. 2016. Pigments and plastic in limnetic ecosystems: A qualitative and quantitative study on microparticles of different size classes. Water Research, 98, 64-74.

IMHOF, H. K., SIGL, R., BRAUER, E., FEYL, S., GIESEMANN, P., KLINK, S., LEUPOLZ. K., LÖDER, M. G., LÖSCHEL, L. A., MISSUN, J., MUSZYNSKI, S., RAMSPERGER, A. F., SCHRANK. I., SPECK, S. STEIBL, S., TROTTER, B., WINTER, I. \& LAFORSCH, C. 2017. Spatial and temporal variation of macro-, meso- and microplastic abundance on a remote coral island of the Maldives, Indian Ocean. Marine Pollution Bulletin, 116, 340-347.

IVAR DO SUL, J. A., COSTA, M. F., BARLETTA, M. \& CYSNEIROS, F. J. A. 2013. Pelagic microplastics around an archipelago of the Equatorial Atlantic. Marine Pollution Bulletin, 75, 305-309.

IVAR DO SUL, J. A., COSTA, M. F. \& FILLMANN, G. 2017. Occurrence and characteristics of microplastics on insular beaches in the Western Tropical Atlantic Ocean. PeerJ Preprints, 1-11.

IVAR DO SUL, J. A., SPENGLER, Â. \& COSTA, M. F. 2009. Here, there and everywhere. Small plastic fragments and pellets on beaches of Fernando de Noronha (Equatorial Western Atlantic). Marine Pollution Bulletin, 58, 1236-1238.

LAVERS, J. L., DICKS, L., DICKS, M. R. \& FINGER, A. 2019. Significant plastic accumulation on the Cocos (Keeling) Islands, Australia. Scientific Reports, 9, 7102.

LEE, J., HONG, S., SONG, Y. K., HONG, S. H., JANG, Y. C., JANG, M., HEO, N. W., HAN, G. M., LEE, M. J., KANG, D. \& SHIM, W. J. 2013. Relationships among the abundances of plastic debris in different size classes on beaches in South Korea. Marine Pollution Bulletin, 77, 349-354.

LIMA, E. C. A. \& ZEPPELINI, D. 2015. First survey of Collembola (Hexapoda: Entognatha) fauna in soil of Archipelago Fernando de Noronha, Brazil. Florida Entomologist, 98, 368-369.

LINK, J., SEGAL, B. \& CASARINI, L. M. 2019. Abandoned, lost or otherwise discarded fishing gear in Brazil: A review. Perspectives in Ecology and Conservation, 17, 1-8. 
LIRA, S. M. A., TEIXEIRA, I. Á., LIMA, C. D. M., SANTOS, G. S., LEITÃO, S. N. \& SCHWAMBORN, R. 2014. Spatial and nycthemeral distribution of the zooneuston off Fernando de Noronha, Brazil. Brazilian Journal of Oceanography, 62, 35-45.

MAAß, S., DAPHI, D., LEHMANN, A. \& RILLIG, M. C. 2017. Transport of microplastics by two collembolan species. Environmental Pollution, 225, 456-459.

MANSO, V. D. A.V., MENOR, E. D. A., VALENÇA, L. M. M., NEUMANN, V. H. D. M. L., PEREIRA, N. S., JUNIOR, C. F. A. S. \& SILVA, E. R. M. 2011. Morfodinâmica de Praias Setentrionais da llha de Fernando do Noronha. Journal of Integrated Coastal Zone Management, 11, 327-339.

MARTINS, J. \& SOBRAL, P. 2011. Plastic marine debris on the Portuguese coastline: A matter of size? Marine Pollution Bulletin, 62, 2649-2653.

MISHRA, S., RATH, C. C. \& DAS, A. P. 2019. Marine microfiber pollution: A review on present status and future challenges. Marine Pollution Bulletin, 140, 188-197.

MOHR, L. V, CASTRO, J. W. A., COSTA, P. M. S. \& ALVES, R. J. V. 2009. Ilhas oceânicas brasileiras: da pesquisa ao manejo - volume II. Brasília: MMA/Secretaria de Biodiversidade e Florestas.

MONTEIRO, R. C. P., IVAR DO SUL, J. A. \& COSTA, M. F. 2018. Plastic pollution in islands of the Atlantic Ocean. Environmental Pollution, 238, 103-110.

PALACIOS-VARGAS, J. G., LIMA, E. C. A. \& ZEPPELINI, D. 2013. A New Species of Isotogastrura (Collembola: Isotogastruridae) from Northeastern Brazil. Florida Entomologist, 96, 15791587.

RYAN, P. G., DILLEY, B. J., RONCONI, R. A. \& CONNAN, M. 2019. Rapid increase in Asian bottles in the South Atlantic Ocean indicates major debris inputs from ships. Proceedings of the National Academy of Sciences, 116, 20892-20897.
SCHMUCK, A. M., LAVERS, J. L., STUCKENBROCK, S., SHARP, P. B. \& BOND, A. L. 2017. Geophysical features in fluence the accumulation of beach debris on Caribbean islands. Marine Pollution Bulletin, 121, 45-51.

SCHNURR, R. E., ALBOIU, V., CHAUDHARY, M., CORBETT, R. A., QUANZ, M. E., SANKAR, K., SRAIN, H., THAVARAJAH, V., XANTHOS, D. \& WALKER, T. R. 2018. Reducing marine pollution from single-use plastics (SUPs): A review. Marine Pollution Bulletin, 137, 157-171.

SERAFINI, T. Z., FRANÇA, G. B. \& ANDRIGUETTO-FILHO, J. M. 2010. Ilhas oceânicas brasileiras: biodiversidade conhecida e sua relação com o histórico de uso e ocupação humana. Revista da Gestão Costeira Integrada, 10, 281-301.

STRAMMA, L. \& ENGLAND, M. 1999. On the water masses and mean circulation of the South Atlantic Ocean. Journal of Geophysical Research, 104, 20863-20883.

TCHAMABI, C. C., ARAUJO, M., SILVA, M. \& BOURLÈS, B. 2017. A study of the Brazilian Fernando de Noronha island and Rocas atoll wakes in the tropical Atlantic. Ocean Modelling, 111, 9-18.

VAN CAUWENBERGHE, L., DEVRIESE, L., GALGANI, F., ROBBENS, J. \& JANSSEN, C. R. 2015. Microplastics in sediments: A review of techniques, occurrence and effects. Marine Environmental Research, 111, 5-17.

VAN WIJNEN, J., RAGAS, A. M. J. \& KROEZE, C. 2019. Modelling global river export of microplastics to the marine environment: Sources and future trends. Science of the Total Environment, 673, 392-401.

WANG, W., GAO, H., JIN, S., LI, R. \& NA, G. 2019. The ecotoxicological effects of microplastics on aquatic food web, from primary producer to human: A review. Ecotoxicology and Environmental Safety, 173, 110-117.

YOUNG, A. M. \& ELLIOTT, J. A. 2016. Characterization of microplastic and mesoplastic debris in sediments from Kamilo Beach and Kahuku Beach, Hawai. Marine Pollution Bulletin, 113, 477-482. 